\title{
The Physicochemical and Sensory Qualities of Goat Cheese with Indigenous Probiotic Starter at Different Temperatures and Storage Durations
}

\author{
Triana Setyawardani*, Mardiati Sulistyowati, Kusuma Widayaka, Agustinus Hantoro Djoko Rahardjo, \\ Singgih Sugeng Santoso and Juni Sumarmono \\ Department of Animal Production, Faculty of Animal Science, Universitas Jenderal Soedirman Purwokerto \\ *Corresponding author email: trianaunsoed@gmail.com
}

\begin{abstract}
The research is conducted aiming at analyzing the physical, chemical, and sensory qualities of goat cheese with different temperatures and storage duration. The research materials are goat milk and $L$. plantarum TW14 and L rhamnosus TW2 isolates, and its equipment include a set of cheese production tools, colorimeter, and SEM. The variables analyzed are cheese's physical quality (color and structure), chemical qualities (total titrated lactic acid) and sensory qualities (texture, flavor, aroma, and likeness). The treatment consists of 2 factors, namely the first factor including: storage temperature (freezer and refrigerator) and the second factor: storage duration $(0 ; 15 ; 30 ; 45$ and 60 days) with 3 replication The obtained results indicate that storage temperature does not influence the cheese's brightness level $\left(L^{*}\right), a^{*}$ value (redness), $b^{*}$ value (yellowness) and sensory qualities (texture, flavor, aroma and likeness), yet storage duration influences the cheese's $L^{*}$ value $(P<0.01)$. Storage temperature has significant influence $(P<0.01)$ on the cheese's lactic acid content, while storage duration has insignificant influence $(P>0.05)$ on it. The cheese's structure shows protein aggregate, void and lactic acid bacteria. The conclusion is that frozen-stored goat cheese still has good physical, chemical, and sensory qualities.
\end{abstract}

Keywords: cheese, physical, chemical, sensory, structure

\begin{abstract}
Abstrak. Penelitian dilakukan dengan tujuan menganalisa kualitas fisik, kimia dan sensori keju kambing dengan perbedaan suhu dan lama penyimpanan. Materi penelitian adalah susu kambing dan isolat L. plantarum TW14 dan L. rhamnosus TW2, peralatan seperangkat alat produksi keju, colorimeter, dan SEM. Variabel yang dianalisa adalah sifat fisik keju (warna dan struktur), sifat kimia (jumlah asam laktat tertitrasi) dan sifat sensori keju (tekstur, rasa, aroma dan kesukaan). Perlakuan terdiri dari 2 faktor yaitu faktor pertama adalah : suhu penyimpanan (freezer dan refrigerator) dan faktor kedua adalah lama penyimpanan (0; 15; 30; 45 dan 60 hari) dengan 3 kali ulangan. Hasil yang diperoleh adalah bahwa suhu penyimpanan tidak mempengaruhi tingkat kecerahan keju(L*), nilai a* (kemerahan), b*(kekuningan keju) dan sifat sensori keju (tekstur, rasa, aroma dan kesukaan) tetapi lama penyimpanan mempengaruhi nilai $L^{*}$ keju $(P<0.01)$. Suhu penyimpanan berpengaruh sangat nyata $(P<0.01)$ terhadap kadar asam laktat keju sedangkan lama penyimpanan berpengaruh tidak nyata $(P>0.05)$. Struktur keju terlihat agregat protein, ruang kosong dan bakteri asam laktat. Simpulan adalah keju kambing yang disimpan beku masih memiliki kualitas fisik, kimia dan sensori yang baik.

Kata kunci: keju, fisik, kimia, sensori, struktur
\end{abstract}

\section{Introduction}

Goat cheese is produced to fulfill the world's cheese need which is currently dominated by cow milk cheese. Generally, goat cheese is commonly produced in goat milk producing countries such as those in Africa and around. Physically, goat cheese is whiter and its curd is finer and softer than cow cheese, while its yield is lower than cow cheese. In cheese production, the starter is used to decrease the milk $\mathrm{pH}$, to provide substrates in order for the proteolytic enzyme to work optimally. L. plantarum TW14 and $L$. rhamnosus TW2 are probiotic isolated from goat milk and serve the role of starters in cheese production (Setyawardani et al., 2016).

Cheese is generally stored at cold temperature during the ripening process, where at such temperature the microbe performs biochemical activities and produces the metabolism which can influence the cheese's physical quality. Some studies such as have tested the physical characteristics of goat 
cheese using probiotic bacteria as the starters and the cheese is stored at cold temperature.

It has been a common practice to store cheese at a frozen temperature to maintain its physicochemical and microbiologic qualities and to reduce the possibility for lipolysis to occur. In addition, frozen storage in cheese is required to expand the marketing and lengthen the cheese storage period. In frozen-stored cheese, the FFA value does not increase at the end of frozen storage. This indicates that no fat damage occurs in the cheese stored for 60 days. During the freezing process, no fat globule in the cheese is damaged thanks to the formation of ice crystal when the cheese is frozen-stored (unpublished data). At frozen temperature, ice crystal is formed and in turn it will disrupt the LAB growth and decrease its viability. The research finds that any cheese stored at cold temperature will also have its $L A B$ metabolite and $L A B$ changed, yet they can be maintained up to $9.69 \pm 0.12 \mathrm{log} \mathrm{cfu} / \mathrm{g}$ (Setyawardani et al., 2016). Cheese is a better probiotic bacteria medium than other fermentation products (Oliveira et al., 2012).

Studies on the physical and sensory qualities of goat cheese stored at frozen temperature are relatively rare because of previous researchers general store the cheese at cold temperature and room temperature during the ripening. Therefore, this research is conducted to study the physical and sensory qualities of goat cheese with L.plantarum TW14 and L.rhamnosus TW2 isolates as the starters stored for 60 days at cold and frozen temperatures.

\section{Materials and Methods}

The milk is from Ettawah-crossbreed goats from the farmer group Pegumas Gumelar Banyumas which is brought using a freezer until it reaches the laboratory. The probiotic lactic acid bacteria isolates $L$. plantarum TW14 and $L$. rhamnosus TW2 are isolated from the goat milk (Setyawardani et al., 2011), and the equipments are a set of sensory testing tools and scanning electron microscopy (SEM), and Konica Minolta CR-10 colorimeter.

\section{Cheese production}

The cheese production process is commenced by heating the milk at $62^{\circ} \mathrm{C}$ for 30 minutes and then the temperature is lowered to $40^{\circ} \mathrm{C}$, and the L.plantarum TW 14 and L.rhamnosus TW2 isolates as starters are added at $5 \%$ concentration and $1: 1$ ratio. The milk is incubated until the $\mathrm{pH}$ turns to 6.1 , and then the rennet is inserted and the milk is once again incubated until a pudding-like solid is formed. The next step is filtering to separate the solids from the whey and then the pressing. The cheese curd is then stored at certain temperatures and storage durations according to the treatments.

\section{Cheese Color}

The cheese color is measured using Konica Minolta CR-10 colorimeter with Hunter notation system (Sabbagh et al., 2010). The goat cheese color measurement is assessed from the brightness level (L). The result of color reading using colorimeter takes the form of $L^{*}$, $a^{*}$ and $b^{*}$ values, where $L^{*}$ is the parameter of brightness (the value ranging from $0 \%$ to $100 \%$ ), $a^{*}$ is the parameter of redness and greenness levels (the value ranging from $-60 \%$ [close to green] to $60 \%$ [close to red]), and $b^{*}$ is the parameter of yellowness and blueness levels (the value ranging from -60\% [close to blue] to $60 \%$ [close to yellow] (Pinho et al., 2004)).

Lactic acid content (AOAC [Association of Official Analytical Chemists], 2006)

The cheese sample of $20 \mathrm{~g}$ is grinded to fineness, then it is inserted into the Erlenmeyer flask. To the sample $20 \mathrm{ml}$ purified water and $\mathrm{pp}$ indicator of 1-2 drops are then added. The final step is that the sample is titrated with $\mathrm{N} / 10 \mathrm{NaOH}$ and the formula used to calculated the lactic acid content is as follows: 
Lactic acid $=$ (volume $\mathrm{NaOH}$ used $\times \mathrm{N} \mathrm{NaOH} \times$ 0.009 )/(sample weight) $\times 100 \%$.

\section{Cheese Sensory Test (Rahayu and Nurosiyah, 2008)}

The cheese sample test is performed by semi-trained panelists on the goat cheese's likeness, texture, flavor, and aroma. The cheese sample is taken from the freeezer and cut at $1.5 \times 1.5 \times 1.5 \mathrm{~cm}$ size. Upon adaptation at room temperature, the sample is then placed on a fray and coded with three-digit number. The coffee powder is provided to be neutralizer after an evaluation of sensory for aroma attribute is done, and a glass of drinking water is provided to be neutralizer after an evaluation of sensory for flavor attribute is done. The panelists are asked to determine their likeness level to each cheese sample without comparing between samples. The texture attribute is tested using hand to assess the cheese's texture fineness.

\section{Cheese's texture profile using SEM (Scanning Electron Microscope) (Ali et al., 2009)}

The cheese sample is inserted into glutaraldehyde solution $4 \% \mathrm{w} / \mathrm{v}$ in phosphate buffer at $\mathrm{pH} 7.2$ for 12 hours at $40^{\circ} \mathrm{C}$. The sample is then washed with $0.1 \mathrm{M}$ cocodylate buffer for 10 minutes 3 times. The next step is dehydration process using ethanol gradually at 50, 70, 85, 95 and $100 \% \mathrm{v} / \mathrm{v}$ concentrations. Next, it is dried using freeze drier and coated with gold.

\section{Design}

The experiment used a completely randomized design with a $2 \times 4$ factorial arrangement each with 3 replications. The first factor including: storage temperature (freezer and refrigerator) and the second factor: storage duration ( $0 ; 15 ; 30 ; 45$ and 60 days).

\section{Statistical analysis \\ The obtained data were subjected to analysis of variance (ANOVA), followed by}

Duncan test for the difference among treatments (Software SPSS 17.0).

\section{Results and Discussion}

\section{Cheese Color}

The cheese in general is yellowish white and this color constitutes the cheese's physical quality. The cheese's color is influenced by the milk raw material used. The cheese made of goat milk is whiter than that of cow milk. This whiter color of goat cheese is influenced by the feed that the goat consumes which will influence the milk it produces (McSweeney, 2007). The color in cheese is variedly described as white, pale, and yellow to orange (Wadhwani and McMahon, 2012).

The cheese brightness $\left(L^{*}\right)$ is not influenced by storage temperature (freezer; refrigerator), however storage duration influences the cheese brightness $(P<0.01)$. The cheese brightness during its storage has varied brightness value, where the highest $L^{*}$ value is found in the cheese stored for 15 days in both freezer and refrigerator storages. The lowest $L^{*}$ value at the end of 60- day storage is 72.03 . The cheese brightness value does not give any trend during its storage and the brightness value decreases in 60th day of storage. The result confirms the research by (Pinho et al., 2004; Sabbagh et al., 2010), and (Sánchez-Macías et al., 2010).

The decreased brightness level during the cheese storage is possibly due to the increase in hydrated protein, indicating the decreased amount of free water which will reduce the gleam in the cheese (Sheehan et al., 2005). The bright color in goat milk cheese is the specific color of goat milk and cheese. The high $\mathrm{L}^{*}$ value reflects the low fat and protein contents in the product, and the decrease of existing free water and the increased total solids will reduce the color gleam (Santos et al., 2016). 
Table 1. Influence of different storage temperatures and durations on goat cheese color

\begin{tabular}{|c|c|c|c|c|c|}
\hline \multirow{2}{*}{$\begin{array}{c}\text { Temperature } \\
\left({ }^{\circ} \mathrm{C}\right)\end{array}$} & \multicolumn{5}{|c|}{ Storage time (days) } \\
\hline & 0 & 15 & 30 & 45 & 60 \\
\hline \multicolumn{6}{|l|}{ Freezer } \\
\hline $\mathrm{L}^{*}$ & $84.80 \pm 0.88^{b}$ & $87.80 \pm 1.35^{c}$ & $83.70 \pm 2.19^{b}$ & $85.961 .27^{b c}$ & $72.03 \pm 0.37^{a}$ \\
\hline$a^{8}$ & $-6.20 \pm 3.11$ & $-7.93 \pm 0.56$ & $-8.30 \pm 0.50$ & $-8.33 \pm 0.41$ & $-8.33 \pm 0.55$ \\
\hline$b^{*}$ & $14.73 \pm 1.25^{\mathrm{a}}$ & $13.40 \pm 0.80^{\mathrm{a}}$ & $13.63 \pm 0.90^{\mathrm{a}}$ & $14.80 \pm 0.60^{\mathrm{a}}$ & $15.06 \pm 0.61^{b}$ \\
\hline \multicolumn{6}{|l|}{ refrigerator } \\
\hline $\mathrm{L}^{*}$ & $82.53 \pm 0.75^{b}$ & $85.46 \pm 2.48 c$ & $80.80 \pm 0.43^{b}$ & $82.50 \pm 5.15^{b c}$ & $78.96 \pm 1.96^{a}$ \\
\hline$a^{*}$ & $-8.53 \pm 0.15$ & $-8.80 \pm 0.10$ & $-8.60 \pm 0.17$ & $-8.40 \pm 0.34$ & $-8.90 \pm 0.26$ \\
\hline$b^{*}$ & $14.53 \pm 1.02^{\mathrm{a}}$ & $15.33 \pm 0.30^{\mathrm{a}}$ & $15.23 \pm 0.35^{\mathrm{a}}$ & $16.00 \pm 1.11^{\mathrm{a}}$ & $17.86 \pm 0.70^{b}$ \\
\hline
\end{tabular}

Note: different superscript shows higly significant differences in the same row $P<0.01$ ) $L^{*}=$ brightness value, $a^{*}=$ redness value, $b^{*}=$ yellowness value.

The redness value $\left(a^{*}\right)$ in goat cheese is neither influenced by temperature nor storage duration. a* value ranges from -8.90 to -6.20 . Different temperatures and storage durations result in relatively similar $a^{*}$ values of the cheese; it can be interpreted that storage temperature and the duration for which the cheese is stored does not change the cheese's $a^{*}$ value. Goat milk cheese is whiter than cow milk cheese which is influenced by the raw materials. The a* value found in this research is higher than that found in (Kusuma, 2015) research in cheese yogurt using cow milk as its raw material with $a^{*}$ value ranging from -4.9 to -6.1. The negative $a^{*}$ value is influenced by unstable color and the negative number of $a^{*}$ is related to $L^{*}$ value (Guiné et al., 2016).

The $b^{*}$ value in cheese color is described as the cheese's yellowness value, where storage temperature does not influence the $b^{*}$ value, rather it is the cheese's storage duration which influences the $b^{*}$ value significantly $(P<0.01)$. The $b^{*}$ value increases in the 60th day of cheese storage at both cold and frozen temperature with its highest averaged $b^{*}$ value at 17.86. The increased yellowness color in the cheese is possibly due to the decreased water content during the storage, resulting in the increased total solids and fat ratio, leading to the cheese looking yellower at the end of storage. The carotene pigment lies in the milk fat and thus give yellowness color to the cheese. Fox (2000) explains that one of the reasons for the yellow color to occur in the cheese is the carotenoid pigment in the milk fat. The redness color indicator $\left(a^{*}\right)$ and yellowness indicator $\left(b^{*}\right)$ are the parameters of cheese redness to yellowness measurement.

\section{Lactic acid content}

The research finds that the amount of titrated lactic acid for 0 to 60 days of storage duration has the highest average of $3.77 \pm 0.45$ $\%$ in the cheese stored for 60 days at refrigerator temperature, and the lowest average is found in the storage treatment for 60 days at freezer temperature, i.e. at $1.02 \pm 0.19$ $\%$. The result of analysis of variance indicates that the cheese storage temperature has significant influence $(P>0.01)$ on the cheese's titrated acid, the storage duration up to 60 days has insignificant influence $(P>0.05)$, yet the interaction between storage temperature and duration has significant influence $(P<0.01)$ on the magnitude of cheese's titrated acid. 
Table 2. Influence of different storage temperatures and durations on goat cheese lactic acid (\%)

\begin{tabular}{clccccc}
\hline \multirow{2}{*}{ No. } & Temperature $\left({ }^{\circ} \mathrm{C}\right)$ & \multicolumn{5}{c}{ Storage time (days) } \\
\cline { 3 - 7 } & & 0 & 15 & 30 & 45 & 60 \\
\hline 1 & Freezer & $2.37 \pm 0.37$ & $1.98 \pm 0.20$ & $2.10 \pm 0.10$ & $2.40 \pm 0.00$ & $1.02 \pm 0.18$ \\
2 & Refrigerator & $2.49 \pm 0.49$ & $2.78 \pm 0.15$ & $3.13 \pm 0.19$ & $3.17 \pm 0.70$ & $3.77 \pm 0.45$ \\
\hline
\end{tabular}

The lactic acid content in the cheese stored in refrigerator is higher and significantly different from the cheese stored at freezer temperature. At cold/refrigerator temperature, the cheese's LAB is doing an activity to turn lactose into lactic acid, despite its low progress, resulting in the metabolite produced by $L A B$ to be higher than that produced at frozen/freezer-stored cheese. The produced lactic acid content will influence the cheese's $\mathrm{pH}$, hence the cheese's $\mathrm{pH}$ becomes more acid. At frozen temperature, ice crystals are formed and they will disrupt the LAB growth and decrese the viability. A study proves that the cheese stored at cold temperature also has its metabolite and LAB viability changed, and it can be maintained up to $9.69 \pm 0.12 \mathrm{log} \mathrm{cfu} / \mathrm{g}$ (Setyawardani et al., 2016)

The lactic acid content is correlated with the number of LAB population. Surono (2004) states that the lactic acid generated in a fermentation process can be dissociated and non-dissociated, depending on the medium's $\mathrm{pH}$. Titrated lactic acid increases when the cheese is stored and it is supported by the cheese's $\mathrm{pH}$ value which changes significantly and the cheese made of heated milk will have its $\mathrm{pH}$ decreased during the storage. This result is similar to that of (Olarte et al., 2001) in Cameros cheese which is made of both unpasteurized and pasteurized milks. Titrated acid plays an important role as the basis for all phases of milk coagulation. This includes the aggregation rate process of para-casein micelle and rennet reactivity. Titrated acid also influences the syneresis rate and serves as the determinant of the ease of the milk to turn into cheese. To produce premium quality cheese, any milk with low acidity (hypoacid milk) is generally not used to make a cheese since it produces rheologically undesired cheese curd and it has paste-like texture (Formaggioni et al., 2001).

Lactic acid is one of lactic acid bacteria metabolite products. In this research two LABs are used, namely L. plantarum TW14 and L.rhamnosus TW 2. Lactic acid bacteria L.plantarum TW14 and L. rhamnosus belong to homofermentative bacteria which produces dominant lactic acid (Setyawardani et al., 2011). The amount of lactic acid in a cheese can be detected using titrimeteric method, where acidity is determined by titrating the crude fluid to $\mathrm{N} / 10 \mathrm{NaOH}$ using pp indicator (Yasmin et al., 2013).

\section{Sensory}

The cheese produced in this research is white, with soft consistency, and easily fragile. Goat milk soft cheese is tested by panelist to find out the likeness level to its texture, flavor and aroma. The sensory attribute of goat cheese is the likeness level using ranking method, where ranking 1 for the most-liked sample and ranking 10 for the most-disliked sample.

In terms of goat cheese's texture, different temperatures (refrigerator and freezer) have significant influence $(P<0.01)$, while different ripening durations have insignificant influence as well as their interaction. The generated products have similar textures, yet each has different values. Based on the panelist's test result, the the highest-ranked texture attribute 
is found in the cheese stored in 0 day/the cheese which has not been stored at 0.19 and the lowest-ranked texture attribute is found in the cheese stored for 15 days at -0.25 . The cheese texture is influenced by several components, such as water, protein and fat contents. The high water content in the cheese matrix causes the product to be less elastic, leading to its particles becoming easily loose. The proportion of $\alpha$ s1-casein in goat milk is also low as one of the causes of the soft cheese texture (Thomann et al., 2008). In addition to casein, the fat in the milk along with other
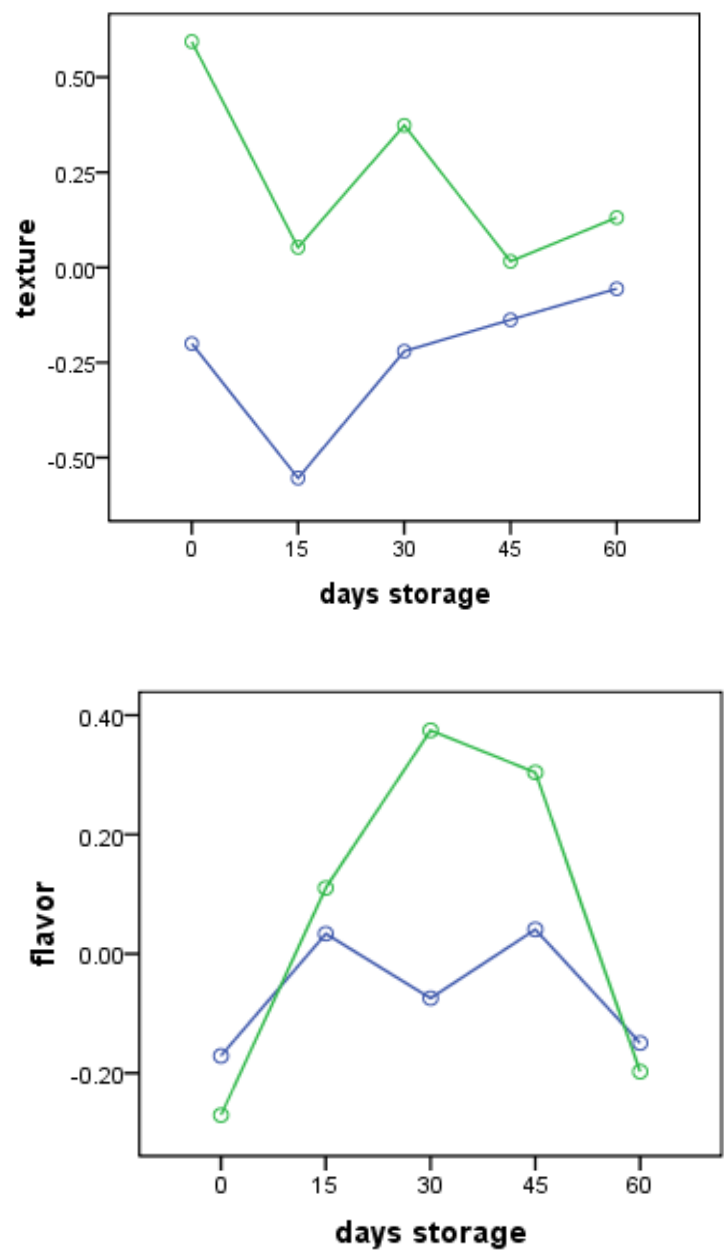

components which do not dissolve in water will be trapped in the coagulated matrix. The smaller fat globule size will cause the fat surface to get bigger and will influence the texture. These components will influence the cheese's hardness, stickiness and flavor (O'Brien and O'Connor, 2004). The water content directly contributes to the formation of cheese texture. Ripening is a change process which will form the characteristics such as cheese's texture, aroma and flavor (McSweeney, 2004).
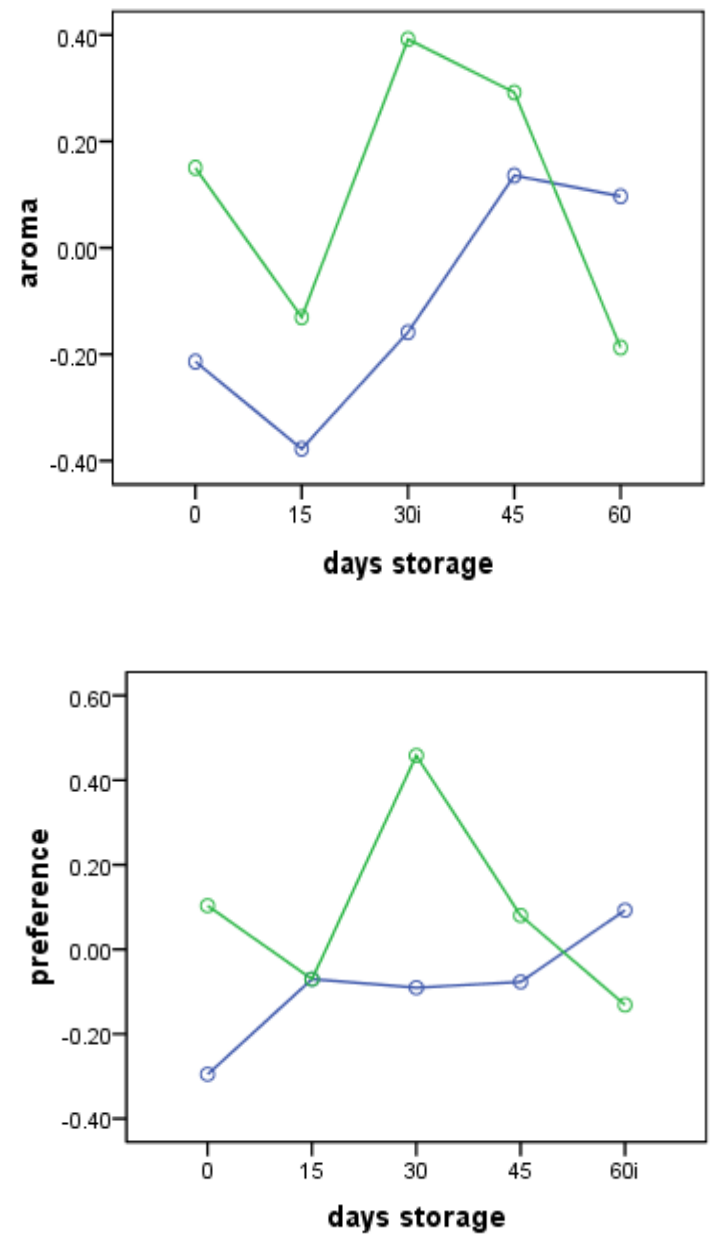

Figure 2. Assessment of goat cheese by panelist by ranking

\section{Cheese flavor}

The goat cheeses stored at different temperatures with different storage durations $(0,15,20,45$ and 60 days) are insignificantly different in terms of their flavor attribute. The sour flavor in cheese is formed from the use of L. rhamnosus TW2 and L. plantarum TW14 bacteria. The valuation by ranking produces 
different values for flavor attribute, where the cheese stored for 45 days has the highest rank at 0.17 and the cheese stored in 0 day (without being stored) has the lowest rank at -0.22 . The sour aroma is formed by the use of $L A B$ culture being added. Lactic acid bacteria reduce the milk $\mathrm{pH}$ by turning the milk lactose into lactic acid. The cheese-specific flavor and aroma are produced from lipolysis, proteolytic and further degradation processes of amino acid by the lactic acid bacteria starter culture and nonstarter culture. The proteolysis product will give cheese flavor directly or plays a role as a precursor compound of the cheese flavor. During the ripening, a biochemical change occurs and the cheese flavor precursor compound is formed. According to Hassan et al. (2013) the compound produced from citrate metabolism process when the cheese is stored will result in flavor attributes such as acetate, diacetyl, acetoin and butanediol compounds.

\section{Cheese aroma}

The goat cheeses stored at refrigerator and freezer temperature for different storage durations up to 60 days do not produce different aroma, both at different temperatures and storages and their interaction $(P>0.05)$. The panelist's valuation results using ranking method generate different values, i.e. the highest rank is found in the sample of cheese stored for 45 days at 0.21 and the lowest rank is found in the goat cheese stored for 15 days at 0.25 . The goat cheese using LAB culture has its specific refreshing sour aroma which can play the role of masking agent to the goaty aroma from goat milk.

The deamination, decarboxylation and transamination processes will generate keto acid, ammonia, amine, aldehyde, acid and alcohol which will eventually form the cheese flavor and aroma. As many as 38 volatile components are identified in Egyptian Ras cheese, which plays a role of generating the cheese-specific flavor and aroma, namely such compounds as alcohol, aldehyde, ketone, esther and others at different concentrations (Ayad et al., 2004). The proteolysis process in cheese when it is stored is influenced by lactic acid bacteria. This process plays some role in the formation of cheese aroma compounds so that a specific aroma is born (Ortigosa et al., 2001; McSweeney, 2004).

\section{Cheese likeness}

The cheese likeness assessed by the panelist is the entire characteristics under assessment of the cheese. The analysis result shows that the different temperatures (cold, frozen) at which the goat cheese is stored does not influence its likeness, likewise the storage duration until 60 days which produces relatively similar likeness. From the results of ranking analysis of the cheese sample tested, the cheese stored for 30 days has the highest rank at 0.18 , and the cheese which is never stored has the lowest likeness rank at -0.96 . Customer's likeness to food products is highly influenced by odor, flavor and oral stimulation, thus a testing if a product's likeness is highly determinant to the acceptance of this product. Some factors influence a cheese's sensory qualities. These factors include the chemical composition, and for this reason microbiology becomes important particularly when it is related to the milk raw material (Coppa et al., 2011). Overal likeness is influenced by the biochemical changes occurring when the cheese is stored. 30-day cheese storage earns the highest rank, this is because the cheese stored for 60 days possibly has higher acidity and it influences the occurrence of secondary proteolysis. This process has caused the likeness to the cheese product to decline (Oliveira et al., 2012).

\section{Cheese texture with SEM}

Many have studied cheese structure at both molecular and microscopic levels using many observation methods. In cheese, this method is used to figure out the protein cluster and the 


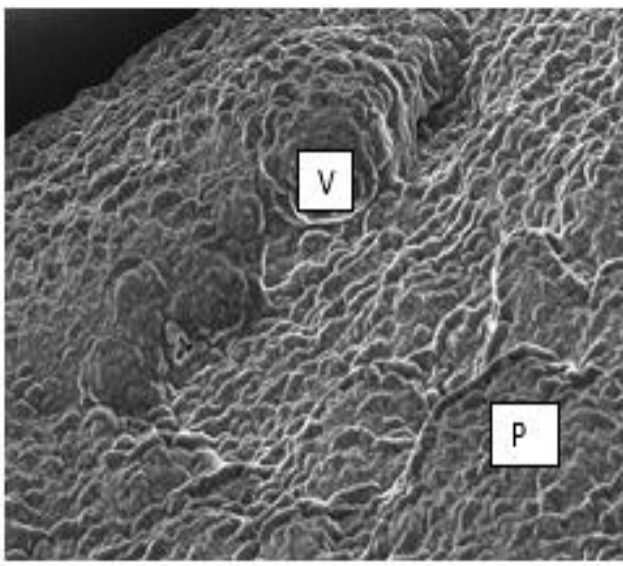

$8.8 \mu \mathrm{m} ; 150 \times$ magnification

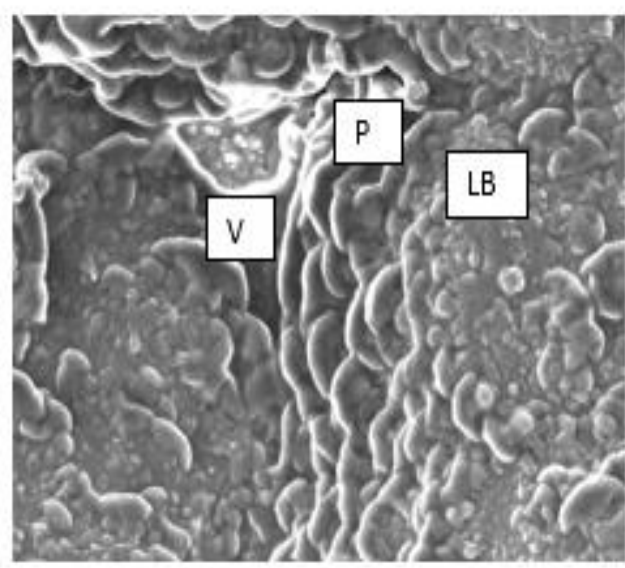

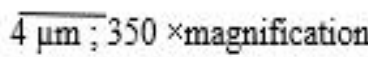

Figure 2. Goat cheese microstructure using SEM (V : void; P : protein aggregates ; LB : Lactobacillus (LAB))

The cheese microstructure formation begins with the arrangement of casein micelle to form protein matrix aggregate (Rovira et al., 2011). In the goat cheese stored for 60 days at frozen storage, protein aggregate is clearly visible, and between the proteins there are void $(\mathrm{V})$. Using SEM, the cheese structure looks like a sponge, where the protein matrix forms a solid tissue (Hussein and Shalaby, 2014). Using micrograph at $350 \times$ zoom, a group of bar-shaped bacteria are seen, these bacteria are used as a starter in cheese production, namely L.plantarum TW14 and L.rhamnosus TW2. The cheese structure is studied using SEM to figure out the protein aggregate size as it is related to the pressure and the ease of the cheese to break, which can be predicted by observing the size of the protein group (Wium et al., 2003).

\section{Conclusions}

The frozen and cold temperatures at which goat cheese is stored do not influence the cheese color and sensory qualities, however storage duration decreases the cheese's brightness level. The lactic acid content of frozen-stored goat cheese is lower than that in the cold-stored cheese and the structure of the cheese does not experience any damage since resulting from the frozen storage as seen using SEM.

\section{References}

Ali, Q., A. J. Farid, B. Kabeir, S. Zamberi, M. Shuhaimi, H. Ghazali, and A. Yazid. 2009. Adhesion properties of Bifidobacterium Pseudocatenulatum G4 and Bifidobacterium Longum BB536 on HT-29 human epithelium cell line at different times and $\mathrm{pH}$. Proc World Acad Sci Eng Tech 37: 149-153.

AOAC [Association of Official Analytical Chemists]. 2006. Official Method of Analysis. $15^{\text {th }} \mathrm{Ed}$. Association of Official Analytical Chemists Inc., Virginia USA.

Ayad, E. H. E., S. Nashat, N. El-Sadek, H. Metwaly, and M. El-Soda. 2004. Selection of wild lactic acid bacteria isolated from traditional Egyptian dairy products according to production and technological criteria. Food. microbiol. 21: 715725.

Coppa, M., I. Verdier-Metz, A. Ferlay, P. Pradel, R. Didienne, A. Farruggia, M. Montel, and B. Martin. 2011. Effect of different grazing systems on upland pastures compared with hay diet on cheese sensory properties evaluated at different ripening times. International dairy journal 21: 815-822.

Formaggioni, P., M. Malacarne, A. Summer, E. Fossa, and P. Mariani. 2001. Milk with abnormal acidity. VI. The role of phosphorus content and the rennet-coagulation properties of Italian Friesian 
herd milks. Annali della Facolta di Medicina Veterinaria, Universita di Parma 21: 261-268.

Guiné, R. P., M. I. Tenreiro, A. C. Correia, P. M. Correia, and P. Barracosa. 2016. Analysis of factors influencing the physical, chemical and sensorial properties of Serra da Estrela cheeses. Journal of Food Measurement and Characterization 10: 643-657.

Hassan, F. A., M. A. M. A. El-Gawad, and A. Enab. 2013. Flavour compounds in cheese (review). Research on Precision Instrument and Machinery 2: 15-29.

Hussein, G. A., and S. M. Shalaby. 2014. Microstructure and textural properties of Kareish cheese manufactured by various ways. Annals of Agricultural Sciences 59: 25-31.

Kusuma, R. 2015. Karakteristik Fisik Dan Mikrobiologi Yogurt Cheese Probiotik Dari Susu Sapi Dengan Kadar Lemak Dan Lama Pemeraman Yang Berbeda. Program Studi Magister IImu Peternakan. Universitas Jenderal Soedirman, Purwokerto.

McSweeney. 2004. Biochemistry of cheese ripening. International Journal of Dairy Technology 57: 127-144.

O'Brien, N. M., and T. P. O'Connor. 2004. Nutritional aspects of cheese. In: P. F. Fox, P. L. H. McSweeney, T. M. Cogan and T. P. Guinee (eds.) Cheese: Chemistry, Physics and Microbiology (Volume 2. Major Cheese Group) No. 2. Elsevier, Amsterdam.

Olarte, C., S. Sanz, E. Gonzalez-Fandos, and P. Torre. 2001. The effect of a commercial starter culture addition on the ripening of an artisanal goat's cheese (Cameros cheese). Journal of Applied Microbiology 88: 421-429.

Oliveira, M. E. G. d., E. F. Garcia, R. d. C. R. d. Queiroga, and E. L. d. Souza. 2012. Technological, physicochemical and sensory characteristics of a Brazilian semi-hard goat cheese (coalho) with added probiotic lactic acid bacteria. Scientia Agricola 69: 370-379.

Ortigosa, M., P. Torre, and J. Izco. 2001. Effect of pasteurization of ewe's milk and use of a native starter culture on the volatile components and sensory characteristics of Roncal cheese. Journal of dairy science 84: 1320-1330.

Pinho, O., E. Mendes, M. Alves, and I. Ferreira. 2004. Chemical, physical, and sensorial characteristics of "Terrincho" ewe cheese: changes during ripening and intravarietal comparison. Journal of Dairy Science 87: 249-257.

Rahayu, P. W., and S. Nurosiyah. 2008. Evaluasi Sensori. Universitas Terbuka, Jakarta.
Rovira, S., M. López, E. Ferrandini, and J. Laencina. 2011. Hot topic: microstructure quantification by scanning electron microscopy and image analysis of goat cheese curd. Journal of dairy science 94: 1091-1097.

Sabbagh, N., H. Gheisari, and M. Aminlari. 2010. Monitoring the chemical and microbiological changes during ripening of Iranian probiotic lowfat white cheese. American Journal of Animal and Veterinary Sciences 5: 249-257.

Sánchez-Macías, D., M. Fresno, I. Moreno-Indias, N. Castro, A. Morales-delaNuez, S. Álvarez, and A. Argüello. 2010. Physicochemical analysis of fullfat, reduced-fat, and low-fat artisan-style goat cheese. Journal of dairy science 93: 3950-3956.

Santos, T. D., B.-H. R. Gonçalves, S. A. Carvalho, and S. AA. 2016. Physical, chemical and sensory characteristics of cream goat cheese produced with Saanen and Alpine milk. In ternational Journal of Engineering Research \& Science 2: 102-111.

Setyawardani, T., W. Rahayu, R. Maheswari, and N. Palupi. 2011. Identification and characterization of probiotic lactic acid bacteria isolated from indigenous goat milk. Animal Production 13.

Setyawardani, T., W. P. Rahayu, and N. S. Palupi. 2016. Physicochemical and stability of goat cheese with mono and mixed culture of Lactobacillus plantarum and Lactobacillus rhamnosus. Animal Production 1: 36-42.

Sheehan, J. J., T. Huppertz, M. G. Hayes, A. L. Kelly, T. P. Beresford, and T. P. Guinee. 2005. High pressure treatment of reduced-fat Mozzarella cheese: Effects on functional and rheological properties. Innovative Food Science \& Emerging Technologies 6: 73-81.

Surono, I. S. 2004. Probiotik Susu Fermentasi dan Kesehatan. YAPMMI, Jakarta.

Thomann, S., A. Brechenmacher, and J. Hinrichs. 2008. Strategy to evaluate cheesemaking properties of milk from different goat breeds. Small Rumin. Res 74: 172-178.

Wadhwani, R., and D. J. McMahon. 2012. Color of low-fat cheese influences flavor perception and consumer liking. Journal of dairy science 95: 2336-2346.

Wium, H., P. Pedersen, and K. Qvist. 2003. Effect of coagulation conditions on the microstructure and the large deformation properties of fat-free Feta cheese made from ultrafiltered milk. Food hydrocolloids 17: 287-296.

Yasmin, A., M. S. Butt, A. Sameen, and M. Shahid. 2013. Physicochemical and amino acid profiling of cheese whey. PJN 12: 455. 